\title{
Long-term treatment with interleukin-1 $\beta$ induces insulin resistance in murine and human adipocytes
}

\author{
C. Lagathu $\cdot$ L. Yvan-Charvet $\cdot$ J.-P. Bastard • \\ M. Maachi • A. Quignard-Boulangé • J. Capeau • \\ M. Caron
}

Received: 22 February 2006 / Accepted: 4 May 2006 / Published online: 25 July 2006

(C) Springer-Verlag 2006

\begin{abstract}
Aims/hypothesis Adipose tissue inflammation has recently been implicated in the pathogenesis of insulin resistance and is probably linked to high local levels of cytokines. IL1B, a proinflammatory cytokine, may participate in this alteration.

Materials and methods We evaluated the chronic effect (1-10 days) of IL1B $(0.1-20 \mathrm{ng} / \mathrm{ml})$ on insulin signalling in differentiating 3T3-F442A and differentiated 3T3-L1 murine adipocytes and in human adipocytes. We also assessed expression of the gene encoding IL1B in adipose tissue of wild-type and insulin-resistant mice (diet-induced and genetically obese $o b / o b$ mice).

Results IL1B inhibited insulin-induced phosphorylation of the insulin receptor $\beta$ subunit, insulin receptor substrate 1, Akt/protein kinase $\mathrm{B}$ and extracellular regulated kinase $1 / 2$ in murine and human adipocytes. Accordingly, IL1B
\end{abstract}

Electronic supplementary material Supplementary material is available in the online version for this article at http://dx.doi.org/ $10.1007 / \mathrm{s} 00125-006-0335-\mathrm{z}$ and is accessible for authorized users.

C. Lagathu · J.-P. Bastard · M. Maachi · J. Capeau · M. Caron $(\bowtie)$ INSERM, U680, Université Pierre et Marie Curie

(UPMC-Paris 6), Faculty of Medicine,

27 rue Chaligny,

75012 Paris, France

e-mail: caron@st-antoine.inserm.fr

J.-P. Bastard $\cdot$ M. Maachi $\cdot$ J. Capeau

Tenon Hospital, Department of Biochemistry and Hormonology,

Paris, France

L. Yvan-Charvet · A. Quignard-Boulangé

INSERM, U671, Université Pierre et Marie Curie

(UPMC-Paris 6), Institut des Cordeliers,

Paris, France suppressed insulin-induced glucose transport and lipogenesis. Long-term treatment of adipose cells with IL1B decreased cellular lipid content. This could result from enhanced lipolysis and/or decreased expression of genes involved in lipid metabolism (acetyl-CoA carboxylase, fatty acid synthase). Down-regulation of peroxisome proliferating-activated receptor $\gamma$ and CCAAT/enhancer-binding protein $\alpha$ in response to IL1B may have contributed to the altered phenotype of IL1B-treated adipocytes. Moreover, IL1B altered adipocyte differentiation status in longterm cultures. IL1B also decreased the production of adiponectin, an adipocyte-specific protein that plays a positive role in insulin sensitivity. Expression of the gene encoding IL1B was increased in epididymal adipose tissue of obese insulin-resistant mice.

Conclusions/interpretation IL1B is upregulated in adipose tissue of obese and insulin-resistant mouse models and may play an important role in the development of insulin resistance in murine and human adipose cells.

Keywords Adiponectin - Adipose tissue - Cytokine . Differentiation · Inflammation · Insulin signalling · Mouse

$\begin{array}{ll}\text { Abbreviations } \\ \text { ACAC } & \text { acetyl-CoA carboxylase } \\ \text { FABP4 } & \text { adipocyte-specific fatty acid binding protein } 4 \\ \text { C/EBP } & \text { CCAAT/enhancer-binding protein } \\ \text { ERK } & \text { extracellular regulated kinase } \\ \text { FASN } & \begin{array}{l}\text { fatty acid synthase } \\ \text { HF }\end{array} \\ \text { hOMA fat } \\ \text { HOMAIR } & \begin{array}{l}\text { homeostasis model assessment-insulin } \\ \text { resistance }\end{array} \\ \text { IR } & \text { insulin receptor } \\ \text { IRS } & \text { insulin receptor substrate }\end{array}$


LF low fat

LPL lipoprotein lipase

$\mathrm{PKB}$ protein kinase $\mathrm{B}$

PPAR peroxisome proliferating-activated receptor

SLC2A4 solute carrier family 2 (facilitated glucose

transporter), member 4 (previously known as GLUT4)

SREBP-1 sterol regulatory element-binding protein 1

WT wild type

\section{Introduction}

Insulin resistance is a prominent feature of the metabolic syndrome, obesity and type 2 diabetes, and is a major risk for cardiovascular disease [1]. It has emerged that obesity and type 2 diabetes are associated with chronic inflammation in adipose tissue, which could play a role in insulin resistance. Increased expression in adipose tissue of key genes involved in inflammation pathways, such as those encoding cytokines and other macrophage-related factors, has been linked to obesity and insulin resistance in mouse and human studies [2-4]. Hence, some cytokines may play a key role in the pathogenesis of insulin resistance.

Many studies have provided clear evidence that circulating levels and adipose tissue expression of TNF- $\alpha$ and IL6 are elevated in obese subjects and subjects with type 2 diabetes [5-7]. Only a few studies have implicated IL1B in these diseases. Circulating levels of IL1B are correlated with the BMI of obese alcoholic subjects [8] and are increased in overweight and obese compared with lean subjects [9]. Moreover, individuals with a combined increase in IL1B and IL6 levels are at greater risk of developing type 2 diabetes than individuals with an increase in the IL6 level alone [10]. In adipose tissue from obese subjects, the total release of IL1B was comparable to that of TNF- $\alpha$, and it originated from non-adipose cells [11]. Expression of $I L 1 B$, the human gene encoding IL1B, is increased in the visceral adipose tissue of obese subjects [12]. In addition, treatment of human adipose tissue explants with IL1B decreased the level of mRNA for adiponectin [13], an adipocyte-secreted protein that plays a positive role in insulin sensitivity $[14,15]$. In adipose tissue and isolated adipocytes, IL1B has been shown to upregulate the release and expression of IL6 [16, 17]. IL1B could also play a role in the increased production of monocyte chemoattractant protein $1[18,19]$, a chemokine involved in the recruitment of macrophages to inflammation sites and the mRNA content of which is elevated in adipose tissue of obese subjects [20]. Thus, IL1B may have a permissive role in the IL6-mediated acute-phase response that precedes the onset of type 2 diabetes $[5,10]$. IL1 receptor antagonist, which inhibits the binding of IL1A and IL1B to their receptors, is also overexpressed in the adipose tissue of mice with diet-induced and genetic obesity, as it is also in the subcutaneous adipose tissue of obese patients $[12,21$, 22]. These increased levels of IL1 receptor antagonist in human obesity could contribute to the development of insulin resistance [22]. All these findings support the hypothesis that IL1 signalling pathways - more specifically, IL1B signalling in adipose tissue-may play an important role in obesity-linked insulin resistance.

IL1B, IL6 and TNF- $\alpha$ are produced mainly by macrophages activated during the inflammatory process [23, 24], but adipocytes and preadipocytes also produce these proinflammatory cytokines [25-27]. Many studies have shown that TNF- $\alpha$ and IL6 induce insulin resistance in adipocytes, including at the insulin receptor level $[25,28-$ 30 ], but no data are available on the direct impact of IL1B on insulin signalling in adipocytes.

We examined whether long-term treatment of murine adipocytes (differentiating 3T3-F442A cells and differentiated 3T3-L1 adipocytes) and primary human adipocytes with IL1B $(0.1-20 \mathrm{ng} / \mathrm{ml})$ affected insulin signalling and insulin-dependent processes (glucose transport and lipogenesis). We then examined the intracellular lipid content and lipid metabolism of IL1B-treated cells. Finally, we investigated whether the expression of $I l l b$ is increased in adipose tissue from mice with genetic $(o b / o b)$ or dietinduced insulin resistance.

\section{Materials and methods}

Cell culture and treatment

Murine 3T3-F442A and 3T3-L1 preadipocytes were cultured and induced to differentiate as described previously [26]. Human preadipocytes (Zen-Bio, Research Triangle Park, NC, USA) were maintained in DMEM/Ham's F-12 with $10 \%$ fetal bovine serum in $5 \% \mathrm{CO}_{2}$ at $37^{\circ} \mathrm{C}$. When the cells became $90 \%$ confluent, differentiation to adipocytes was induced using DMEM/F-12 containing 3\% fetal bovine serum, $10 \mathrm{nmol} / 1$ insulin, $1 \mu \mathrm{mol} / 1$ dexamethasone, $0.20 \mathrm{mmol} / 1$ isobutylmethylxanthine (IBMX) and $10 \mu \mathrm{mol} / 1$ rosiglitazone. After 3 days, IBMX and rosiglitazone were removed from the medium. Recombinant mouse IL1B was purchased from R\&D Systems (Minneapolis, MN, USA). The effect of IL1B $(0.1-20 \mathrm{ng} / \mathrm{ml})$ was tested in long-term experiments with differentiating 3T3F442A cells (from day 0 [confluence] to day 8 of differentiation), differentiated 3T3-L1 adipocytes (from days 8 to 14 or 18 of differentiation) and differentiated human adipocytes (from days 22 to 28 of differentiation). 
The cytotoxicity of IL1B was evaluated with the 3-[4,5-2yl]-2,5 diphenyltetrazolium bromide (MTT) test on day 8 (3T3-F442A cells), days 14 and 18 (3T3-L1 cells) and day 28 (human adipocytes) of differentiation.

\section{Western blotting}

Cells were solubilised in Laemmli buffer with $100 \mathrm{mmol} / \mathrm{l}$ dithiothreitol. Cell lysates $\left(10^{4}\right.$ cells $)$ were subjected to SDS-PAGE and Western blotting with antibodies to sterol regulatory element-binding protein 1 (SREBP-1) (antibody K-10), CCAAT/enhancer-binding protein $(\mathrm{C} / \mathrm{EBP} \alpha)(\mathrm{C}-19)$, peroxisome proliferating-activated receptor (PPAR) $\gamma(\mathrm{H}-100), \mathrm{C} / \mathrm{EBP} \beta$ (C-19) and solute carrier family 2 (facilitated glucose transporter), member 4 (SLC2A4, previously known as GLUT4) (H-61), obtained from Santa Cruz Biotechnology (Santa Cruz, CA, USA). Cell lysates were prepared at day 8 (3T3-F442A cells), 14 (3T3-L1 adipocytes) or 28 (human adipocytes) of differentiation, using cells cultured for $18 \mathrm{~h}$ in serum-free medium. Cells were stimulated for $10 \mathrm{~min}$ with $100 \mathrm{nmol} / 1$ insulin. Aliquots of cell lysates were immunoblotted with an anti-phosphotyrosine antibody (PY-99), with antibodies anti-phospho extracellular regulated kinase (ERK)1/2-tyr204 (E-4) (Santa Cruz Biotechnology) or antiphospho-Akt-ser473 (catalogue no. 9271) (Cell Signaling Technology, Danvers, MA, USA). Protein expression was checked by using antibodies directed against insulin receptor (IR) $\beta$ (C-19), insulin receptor substrate (IRS)-1 (C-20), ERK1/2 (C-16) (Santa Cruz Biotechnology) or Akt/ protein kinase B (PKB) (catalogue no. 9272; Cell Signaling Technology). Immune complexes were visualised with a chemiluminescence method (ECL kit; Amersham Biosciences, Saclay, France). Protein expression, determined by Western blotting, was normalised to the cell number. The relative protein expression in each sample was quantified by chemiluminescence using a ChemiGenius2 image analyser and software (Ozyme, St Quentin en Yvelines, France).

Lipogenesis and glucose transport

Insulin-stimulated lipogenesis and glucose transport were studied on day 8 (3T3-F442A cells) or 14 (3T3-L1 adipocytes) of differentiation in cells cultured for $18 \mathrm{~h}$ in serum-free medium, as described previously [25]. Glucose transport results were expressed as pmol of 2-deoxy-glucose per 10 cells per $5 \mathrm{~min} \pm \mathrm{SEM}$, and lipogenesis as pmol of glucose incorporated into lipids per $10^{6}$ cells per $\mathrm{h} \pm \mathrm{SEM}$.

Oil Red O lipid staining and lipolysis

On day 8 (3T3-F442A cells), 14 and 18 (3T3-L1 cells) or 28 (human adipocytes) of differentiation, lipid accumula- tion was assessed by lipid staining with Oil Red O. Staining was quantified at $520 \mathrm{~nm}$ after solubilisation in $10 \%$ SDS. Results are expressed as the percentage \pm SEM of the untreated control value (100\%). Glycerol release was assessed in 24-h culture supernatants by using the enzymatic BioAnalysis kit from Boehringer Mannheim (Darmstadt, Germany). Results were expressed as $\mu \mathrm{g}$ of glycerol per $10^{6}$ cells per $24 \mathrm{~h} \pm \mathrm{SEM}$.

\section{Adiponectin measurements}

Adiponectin concentrations were determined on days 8 (3T3-F442A cells), 14 (3T3-L1 cells) and 28 (human adipocytes) of differentiation in 24-h supernatants by using the ELISA murine kit from B-Bridge International (Sunnyvale, CA, USA) or the ELISA human kit from R\&D Systems.

Animal study

Male C57BL/6 mice were fed from weaning to 13 weeks of age with either a low-fat diet (Wild-type [WT]-LF; 4\% fat $\mathrm{wt} / \mathrm{wt}$ ) or a high-fat diet (WT-HF; $25 \%$ fat $\mathrm{wt} / \mathrm{wt}$ ), as described previously [31]. Thirteen-week-old C57BL/6 ob/ $o b$ male mice and littermate controls were purchased from Charles River Laboratories (Wilmington, MA, USA). All animal experiments were performed according to the French guidelines for care and use of experimental animals. Blood was collected into heparinised tubes by cardiac puncture. Fasting glucose was assayed with a glucometer (Roche Diagnostics, Meylan, France) and fasting insulin was determined by radioimmunoassay (CIS Biointernational, Gif sur Yvette, France). Insulin resistance was quantified in terms of homeostasis model assessment-insulin resistance $($ HOMA-IR) as fasting glucose $(\mathrm{mmol} / \mathrm{l}) \times$ fasting insulin $(\mathrm{mU} / \mathrm{l}) / 22.5$.

\section{RNA preparation and real-time RT-PCR}

Total RNA was extracted from 3T3-F442A (day 8) and 3T3-L1 (day 14) cells and human adipocytes (day 28) and cDNA was synthesised as described previously [26]. Total RNA was isolated from mouse epididymal adipose tissue as described previously [32] and cDNA was synthesised from $1 \mu \mathrm{g}$ of total RNA with Superscript reverse transcriptase (Invitrogen, Cergy-Pontoise, France). Real-time PCR was performed with the LightCycler system (Roche Diagnostics, Meylan, France) and the LightCycler SYBR green fluorophore. A list of primer sequences is given in the Electronic Supplementary Material (ESM). Results were expressed as percentage \pm SEM of untreated control values $(100 \%)$ normalised to 18S RNA expression. 


\section{Statistical analysis}

Results are mean \pm SEM of the indicated number of independent experiments. Statistical significance was determined with parametric (Student's $t$ ) and non-parametric (Mann-Whitney $U$ ) tests, as appropriate. The significance of correlations was determined by using the non-parametric Spearman's rank correlation test. The threshold of significance was set at $p=0.05$.

\section{Results}

IL1B induces insulin resistance in murine 3T3-F442A and 3T3-L1 adipocytes

We first examined whether long-term treatment with IL1B altered insulin signal transduction in differentiating 3T3F442A (8 days of treatment) and differentiated 3T3-L1 adipocytes (6 days of treatment). Western blot analysis showed that IL1B (10 or $20 \mathrm{ng} / \mathrm{ml}$ ) did not alter the expression of IR $\beta$ (Fig. 1a,b) or its major substrate, IRS-1 (Fig. 1c,d). However, IL1B inhibited acute activation by insulin of tyrosine phosphorylation of IR $\beta$ and IRS- 1 in both cell lines, in a concentration-dependent manner (Fig. 1a-d). Furthermore, in differentiating and differentiated adipocytes, IL1B reduced by $40-75 \%$ the insulin-induced activation of Akt/PKB, a key enzyme of the insulin signalling pathway mainly involved in short-term metabolic responses (Fig. 1e,f); it also reduced by $45-75 \%$ the insulin-induced activation of ERK1/2, a mitogen-activated protein kinase that mediates part of the insulin response on transcription (Fig. 1g,h). Lower concentrations of IL1B $(0.1$ and $1 \mathrm{ng} / \mathrm{ml})$ also inhibited acute insulin-induced phosphorylation of Akt/ PKB (by 25 and 35\%, respectively) and ERK1/2 (by 20 and $40 \%$, respectively) in 3T3-L1 adipocytes. Shorter times of incubation with IL1B (24 h) also blunted insulin-induced phosphorylation of Akt/PKB (by 50, 60 and $80 \%$ at 1,10 and $20 \mathrm{ng} / \mathrm{ml}$, respectively) and ERK1/2 (by 30,55 and $65 \%$ at 1,10 and $20 \mathrm{ng} / \mathrm{ml}$, respectively). These results indicated that IL1B can induce insulin resistance after incubation for $24 \mathrm{~h}$ and at low concentrations.
Fig. 1 IL1B alters insulin signalling in 3T3-F442A and 3T3$\mathrm{L} 1$ adipocytes. Differentiating 3T3-F442A cells (from days 0 to 8 ) and fully differentiated 3T3-L1 adipocytes (from days 8 to 14) were treated with IL1B at the concentration indicated. On day 8 (3T3-F442A) (a, c, e, g) or 14 (3T3-L1) (b, d, f, h) of differentiation, cells were stimulated for $10 \mathrm{~min}$ with $100 \mathrm{nmol} / \mathrm{l}$ insulin. Proteins were extracted and analysed by immunoblotting. Representative blots are shown of $\mathbf{a}, \mathbf{b}$ the insulin receptor $\beta$ subunit $(\operatorname{IR} \beta)$ and its insulin-stimulated tyrosine phosphorylation (Phospho-IR $\beta)$, c, d IRS-1 and its insulin-stimulated tyrosine phosphorylation (PhosphoIRS-1), e, f Akt/PKB and its phosphorylated form (Phospho $A k t / P K B)$ and g, h ERK1/2 and its phosphorylated form (Phospho ERK1/2). Scanned data, expressed in arbitrary units $(A U)$, are shown below and represent insulin-stimulated samples compared with their respective control sample (1.0) normalised to their protein level. Results are mean \pm SEM of three or four experiments. ${ }^{*} p<0.05, * * p<0.01,{ }^{* * *} p<0.001$ a
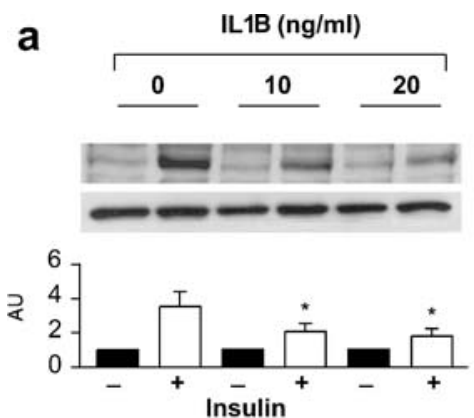

C
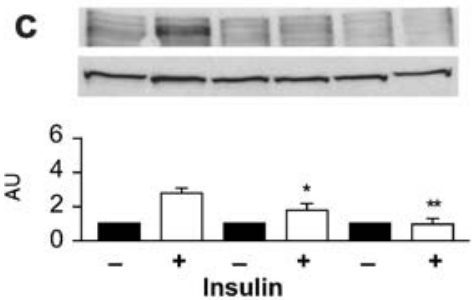

e
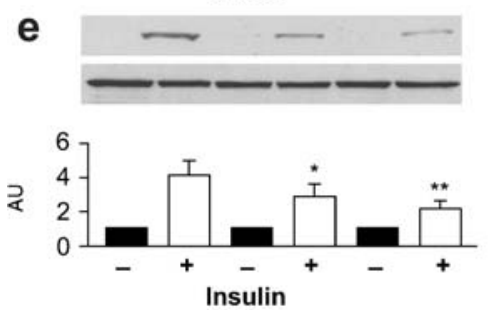

g
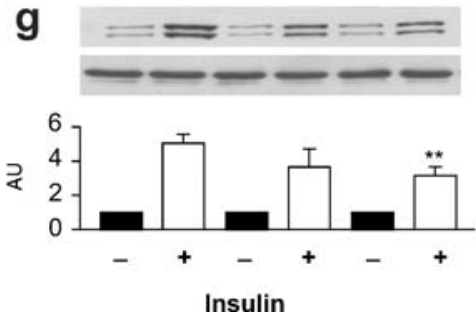

b

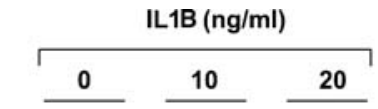

Phospho IR $\beta$

$\operatorname{IR} \beta$
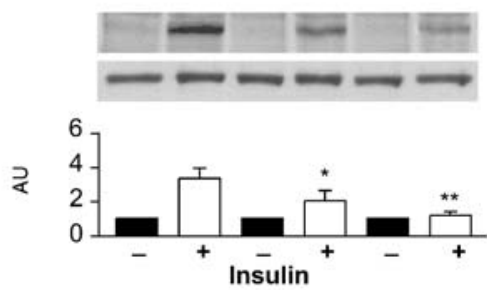

Phospho IRS-1

IRS-1
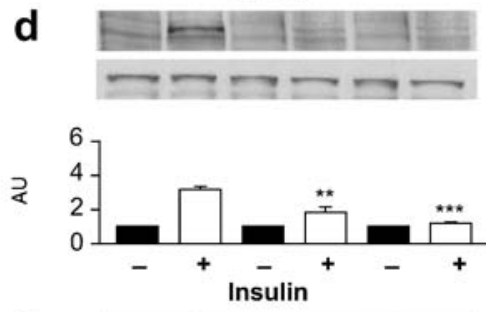

Phospho Akt/PKB f
Akt/PKB

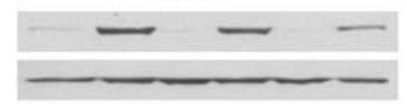

२

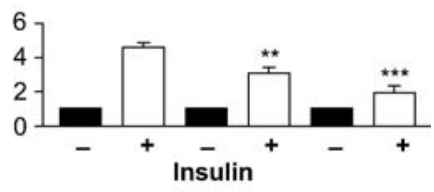

Phospho ERK1/2

ERK $1 / 2$

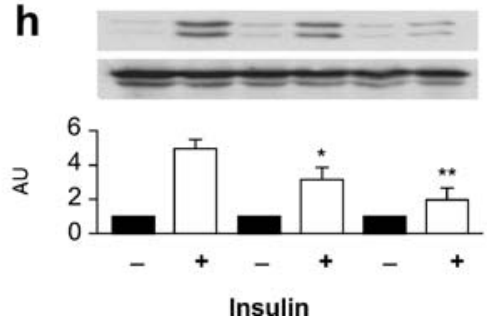


We then examined the effect of IL1B on lipogenesis and glucose transport (Fig. 2). IL1B significantly altered basal glucose transport in differentiating 3T3-F442A cells but not in differentiated 3T3-L1 cells, and strongly inhibited insulin-stimulated glucose transport in both cell lines (by up to $86 \%$ in $3 \mathrm{~T} 3-\mathrm{F} 442 \mathrm{~A}$ cells and up to $84 \%$ in $3 \mathrm{~T} 3-\mathrm{L} 1$ cells) (Fig. 2a,b). IL1B had only a moderate effect on Slc2a4 mRNA expression (Table 1) and no effect on SLC2A4 protein level (Fig. 2c,d), suggesting that IL1B altered the insulin-induced membrane translocation of SLC2A4. Moreover, IL1B did not modify the basal level of lipogenesis in 3T3-F442A or 3T3-L1 cells, but markedly reduced insulin-induced lipogenesis in both cell lines (by up to $96 \%$ in $3 \mathrm{~T} 3-\mathrm{F} 442 \mathrm{~A}$ cells and up to $93 \%$ in $3 \mathrm{~T} 3-\mathrm{L} 1$ cells) (Fig. 2e,f). This is in agreement with the decreased level of transcripts of the genes encoding lipogenic enzymes (fatty acid synthase [Fasn] and acetyl-CoA carboxylase $[A c a c]$ ) in both cell lines treated by IL1B (Table 1).
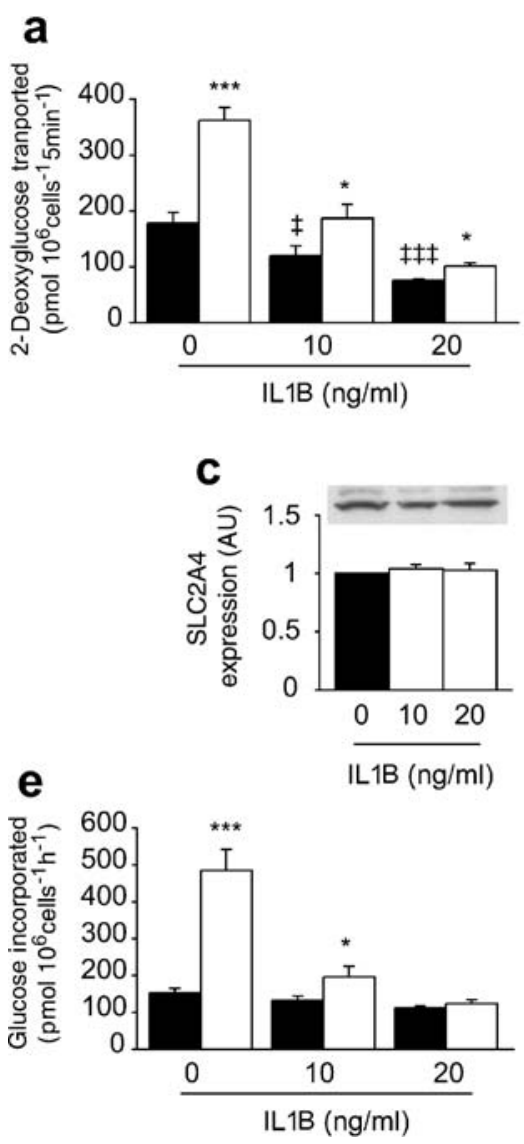

Fig. 2 IL1B alters insulin-stimulated lipogenesis and glucose transport in 3T3-F442A and 3T3-L1 adipocytes. Murine adipocytes were treated with IL1B as described (Fig. 1 legend). On day 8 (3T3-F442A) (a) or 14 (3T3-L1) (b) 2-deoxy-D- $\left[{ }^{14} \mathrm{C}\right]$-glucose transport was evaluated (see Materials and methods). Results \pm SEM. On day 8 (3T3-F442A) (c) or 14 (3T3-L1) (d), proteins were extracted from IL1B-treated and untreated cells and analysed by immunoblotting; representative immunoblots of SLC2A4 and the scanned data
IL1B reduces lipid content in murine differentiating 3T3-F442A and differentiated 3T3-L1 adipocytes

In 3T3-F442A cells, IL1B prevented the lipid accumulation that normally occurs during the differentiation process, as shown by a 30 and $50 \%$ decrease in Oil Red O lipid staining after 8 days of treatment at 10 and $20 \mathrm{ng} / \mathrm{ml}$, respectively (Fig. 3a). The effect of IL1B was time-dependent in differentiated 3T3-L1 adipocytes. Six days of treatment of 3T3-L1 cells with IL1B did not significantly alter the lipid content (Fig. 3b). By contrast, the lipid content fell in 3T3L1 cells treated for 10 days (by 43 and $60 \%$ at 10 and $20 \mathrm{ng} /$ $\mathrm{ml}$, respectively) (Fig. 3b). This was confirmed by the ability of IL1B to increase the basal rate of lipolysis (glycerol release) in 3T3-L1 adipocytes (2.2- to 2.8-fold after 6 days; 2.4- to 3.4-fold after 10 days at 10 and $20 \mathrm{ng} / \mathrm{ml}$, respectively) (Fig. 3d). IL1B had no effect on the basal rate of lipolysis in 3T3-F442A differentiating adipocytes (Fig. 3c) or on the mRNA expression of hormone-sensitive lipase
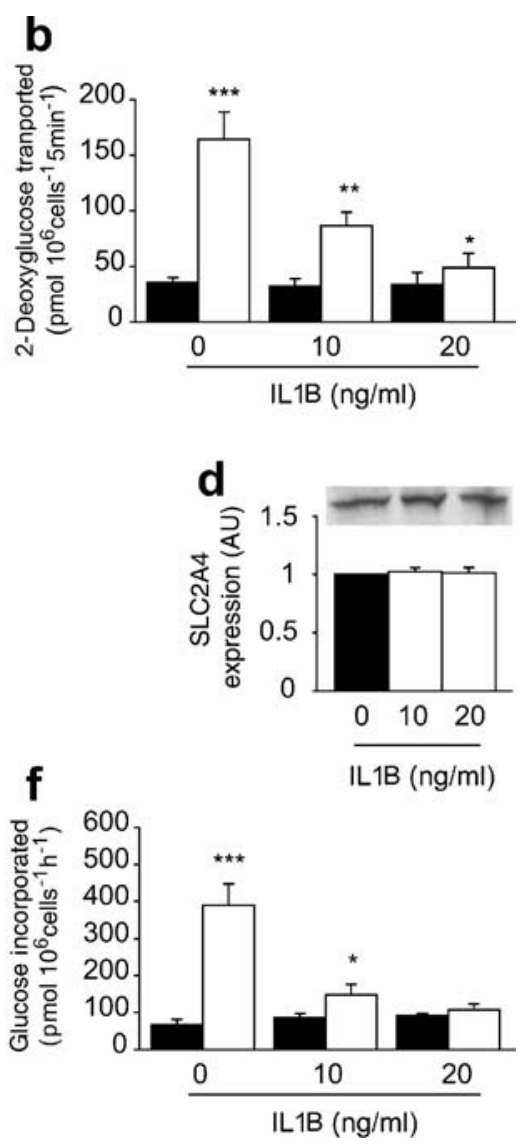

(arbitrary units $[A U])$ of three experiments are also shown. On day 8 (3T3-F442A) (e) or 14 (3T3-L1) (f) of differentiation, $\left[{ }^{14} \mathrm{C}\right]$-glucose incorporation into lipids was evaluated (see Materials and methods). Results \pm SEM. The experiments were repeated three times on triplicate samples. Insulin-stimulated values (open bars) vs basal values (solid bars): ${ }^{*} p<0.05, * * p<0.01, * * * p<0.001$. Control basal value vs IL1B-treated basal value: $₫ p<0.05$, $\$+\ddagger p<0.001$ 
Table 1 Chronic effects of IL1B on the expression of adipogenic markers in 3T3-F442A cells and 3T3-L1 adipocytes

\begin{tabular}{|c|c|c|c|c|c|c|}
\hline & \multicolumn{3}{|c|}{ 3T3-F442A cells } & \multicolumn{3}{|c|}{ 3T3-L1 cells } \\
\hline & \multicolumn{3}{|l|}{ IL1B } & \multicolumn{3}{|l|}{ IL1B } \\
\hline & None & $10 \mathrm{ng} / \mathrm{ml}$ & $20 \mathrm{ng} / \mathrm{ml}$ & None & $10 \mathrm{ng} / \mathrm{ml}$ & $20 \mathrm{ng} / \mathrm{ml}$ \\
\hline Slc2a4 & 100 & $89.6 \pm 30.9$ & $76.0 \pm 14.5^{\mathrm{a}}$ & 100 & $91.0 \pm 9.3$ & $78.3 \pm 15.3$ \\
\hline Fasn & 100 & $70.2 \pm 6.9^{\mathrm{b}}$ & $51.8 \pm 8.1^{\mathrm{c}}$ & 100 & $46.8 \pm 4.8^{\mathrm{b}}$ & $51.5 \pm 6.5^{\mathrm{c}}$ \\
\hline Acac & 100 & $65.0 \pm 8.4^{\mathrm{a}}$ & $53.6 \pm 14.2^{\mathrm{a}}$ & 100 & $73.5 \pm 18.6$ & $44.2 \pm 9.7^{\mathrm{c}}$ \\
\hline Fabp4 & 100 & $84.7 \pm 6.5$ & $59.0 \pm 4.1^{\mathrm{b}}$ & 100 & $83.2 \pm 16.1$ & $66.3 \pm 12.9^{\mathrm{a}}$ \\
\hline$L p l$ & 100 & $64.5 \pm 10.8^{\mathrm{a}}$ & $48.8 \pm 13.7^{\mathrm{a}}$ & 100 & $76.0 \pm 6.7^{\mathrm{a}}$ & $65.8 \pm 7.3^{\mathrm{b}}$ \\
\hline
\end{tabular}

mRNA levels, normalised to $18 \mathrm{~S}$ rRNA expression, were determined relative to untreated cells (100). Results are expressed as percentage \pm SEM of control values in three experiments performed in triplicate

${ }^{\mathrm{a}} p<0.05,{ }^{\mathrm{b}} p<0.01,{ }^{\mathrm{c}} p<0.001$ vs untreated cells

$(H s l)$ in either differentiating or differentiated cells (data not shown). The expression of major lipid markers (Fasn, Acac, $\mathrm{Lpl}$ [lipoprotein lipase] and adipocyte-specific fatty acid binding protein [Fabp 4]) was reduced in cells treated during differentiation (3T3-F442A) or after completion of differentiation (3T3-L1) (Table 1), which may contribute to the decreased lipid content observed in both cell lines.

As the lipid content and insulin sensitivity of adipocytes are closely related to the differentiation status of the cells, we examined the protein level of the main transcription factors involved in adipogenesis. In differentiating 3T3F442A adipocytes, IL1B reduced PPAR $\gamma$ and $\mathrm{C} / \mathrm{EBP} \alpha$ levels and prevented the differentiation-associated fall in $\mathrm{C} /$ EBP $\beta$, without affecting SREBP-1 (Fig. 4a). These results suggest that IL1B can partly alter the adipose cell differentiation programme. By contrast, differentiated 3T3L1 adipocytes treated with IL1B for 6 days showed normal levels of these transcription factors (Fig. 4b). Ten days of a

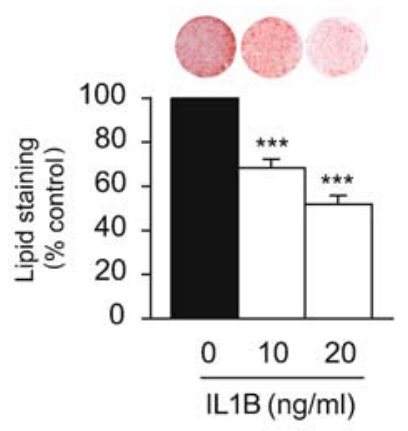

C

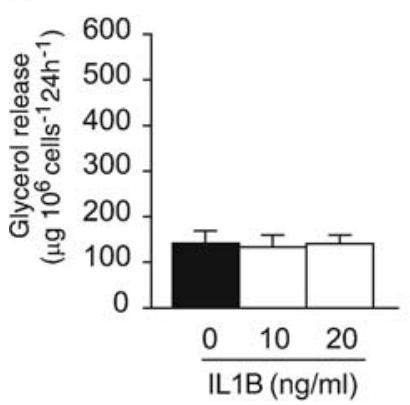

b

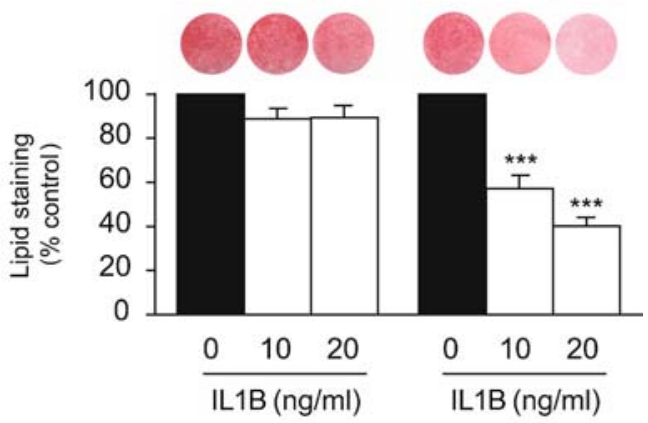

d

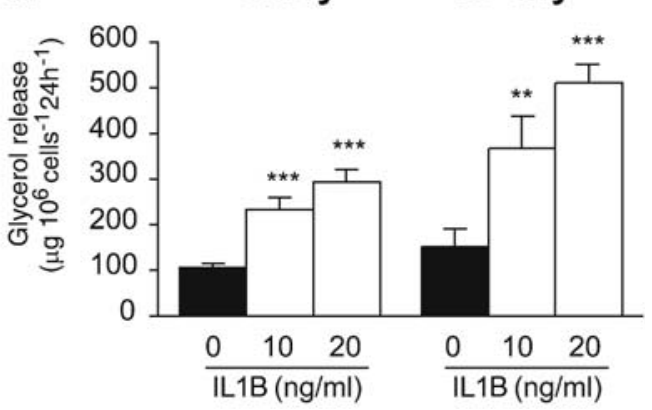

Fig. 3 IL1B alters the lipid status of 3T3-F442A and 3T3-L1 adipocytes. Murine adipocytes were treated with IL1B as described (legend Fig. 1). After 8 days (3T3-F442A) (a) or 6 or 10 days (3T3L1) (b) of IL1B treatment, cells were fixed and stained with Oil Red O. Staining was quantified at $520 \mathrm{~nm}$ and expressed as the percentage of untreated controls \pm SEM for three experiments performed in duplicate. After 8 days (3T3-F442A) (c) and 6 or 10 days (3T3-L1) (d) of IL1B treatment, the medium was replaced and, $24 \mathrm{~h}$ later, basal glycerol release was determined by using an enzymatic bio-analysis kit (see Materials and methods). Results \pm SEM for three or four experiments performed in duplicate. ${ }^{* *} p<0.01$, $* * * p<0.001$ vs control (filled bars) 
Fig. 4 IL1B decreases the level of adipogenic transcription factors in 3T3-F442A cells and 3T3-L1 adipocytes. Murine adipocytes were treated with IL1B (see Fig. 1). After 8 days (3T3$\mathrm{F} 442 \mathrm{~A})$ (a) or 6 or 10 days (3T3-L1) (b), IL1B-treated and untreated cells were solubilised and aliquots were immunoblotted with anti-C/EBP $\beta, \mathrm{C} / \mathrm{EBP} \alpha$, SREBP-1 and PPAR $\gamma$ antibodies. A representative immunoblot from three separate experiments is shown a

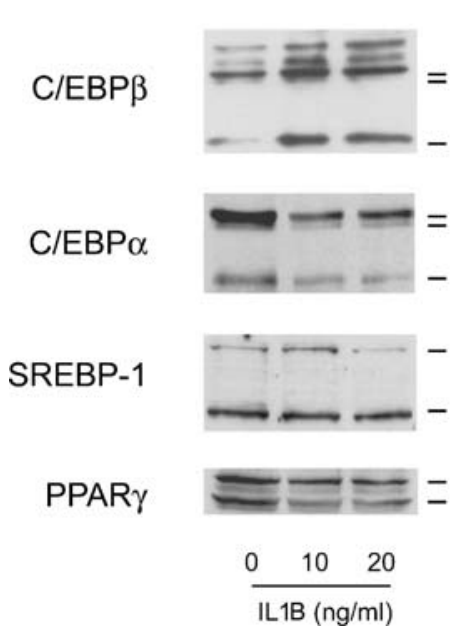

b

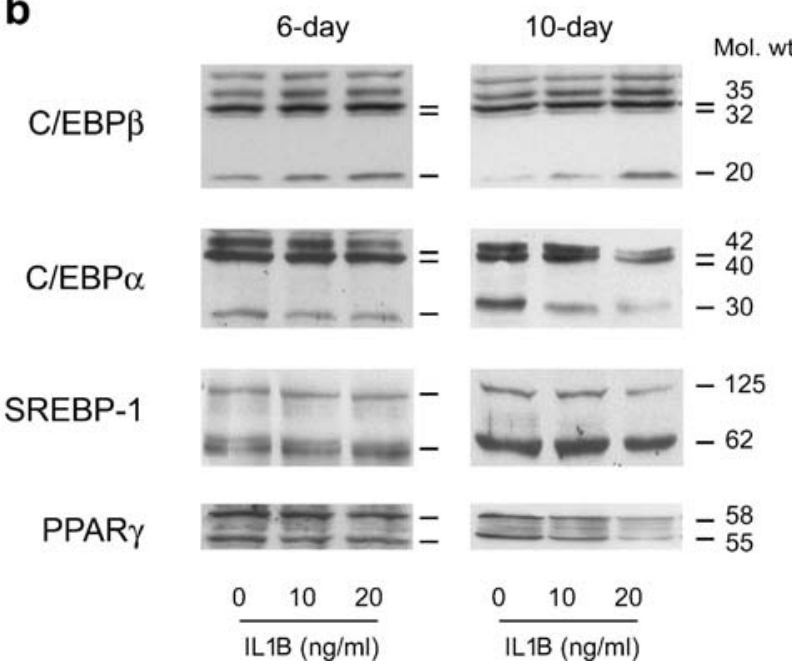

treatment with IL1B reduced $\mathrm{C} / \mathrm{EBP} \alpha$ and $\operatorname{PPAR} \gamma$ and enhanced $\mathrm{C} / \operatorname{EBP} \beta$ (Fig. 4b), in keeping with the altered lipid phenotype of 3T3-L1 cells. These results are consistent with the observed insulin-resistant state of 3T3-L1 adipocytes, as $\mathrm{C} / \mathrm{EBP} \alpha$ and PPAR $\gamma$ are involved both in the final stages of the differentiation process and in insulin sensitivity [33], and suggest that long-term treatment with IL1B partly alters the differentiation status of the cells.

IL1B induces insulin resistance and decreases lipid content in primary human adipocytes

We next investigated the effect of IL1B in differentiated primary human adipocytes. As shown in Fig. 5, IL1B treatment (from days 22 to 28) at different concentrations $(0.1-20 \mathrm{ng} / \mathrm{ml})$ did not alter the protein levels of the insulin signalling components IR $\beta$, IRS-1, Akt/PKB and ERK1/2 in human adipocytes. However, IL1B at 1, 10 and $20 \mathrm{ng} / \mathrm{ml}$ blunted the ability of insulin to increase the tyrosine phosphorylation of IR $\beta$ (Fig. 5a) and IRS-1 (Fig. 5b) and decreased the insulin-induced activation of $\mathrm{Akt} / \mathrm{PKB}$ (Fig. 5c) and ERK1/2 (Fig. 5d). As observed in the murine adipose cell lines, IL1B decreased the expression of the major transcription factors $\mathrm{C} / \mathrm{EBP} \alpha$ and $\operatorname{PPAR} \gamma$ (at 10 and $20 \mathrm{ng} / \mathrm{ml}$ ) and increased the level of the early transcription factor $\mathrm{C} / \mathrm{EBP} \beta$ (Fig. 6a) in human primary adipocytes. Chronic IL1B (20 ng/ml) treatment also decreased SREBP-1 and the mRNA expression of SLC2A4 and of several proteins involved in lipid metabolism (FASN, $A C A C, F A B P 4$ and $L P l$ ) (Table 2), showing that IL1B altered the lipid status of human adipocytes. Accordingly, IL1B decreased cellular lipid content evaluated by lipid staining with Oil Red $\mathrm{O}$ (by 35, 45 and 55\% at 1, 10 and $20 \mathrm{ng} / \mathrm{ml}$, respectively) (Fig. 6b). Thus, as in murine adipocytes, IL1B induced insulin resistance and altered lipid metabolism and the differentiation status in primary human adipocytes.

IL1B suppresses adiponectin production by murine and human adipocytes

As shown in Fig. 7, IL1B markedly reduced adiponectin secretion by differentiating 3T3-F442A and fully differentiated 3T3-L1 adipocytes (by 50-60 and 50-70\%, respectively) (Fig. 7a,b). IL1B also dramatically decreased adiponectin secretion by human primary adipocytes by 80-90\% (Fig. 7c), which reinforces the relevance of our results to the potential role of IL1B in insulin resistance in human pathophysiology. Accordingly, adiponectin expression fell by $75-85 \%$ in differentiating 3T3-F442A cells (Fig. 7d), by $45-65 \%$ in differentiated 3T3-L1 adipocytes (Fig. 7e), and by $60-80 \%$ in human primary adipocytes treated with IL1B (Fig. 7f).

Elevated IL1B expression in adipose tissue of insulin-resistant mice

To further study the involvement of IL1B in insulin resistance, including obesity-induced insulin resistance, we measured $I l 1 b$ expression in epididymal adipose tissue of mice receiving a high-fat diet (WT-HF) and of genetically obese mice $(o b / o b)$ [34]. After 12 weeks of high-fat feeding, WT-HF mice displayed increased epididymal fat pad weight (1.50-fold) and fasting plasma insulin level (1.85-fold) when compared with wild-type mice fed a low-fat diet (WT-LF) (Table 3). When compared with their wild-type littermates, $o b / o b$ mice exhibited higher epididymal fat pad weight (10.5-fold) and fasting plasma insulin (13.1-fold). As expected, the HOMA-IR [35] index was higher in WT-HF than in WT-LF mice (38.9 vs 21.2) and was higher in $o b / o b$ than in wild-type mice (231.0 vs 19.0) 
a

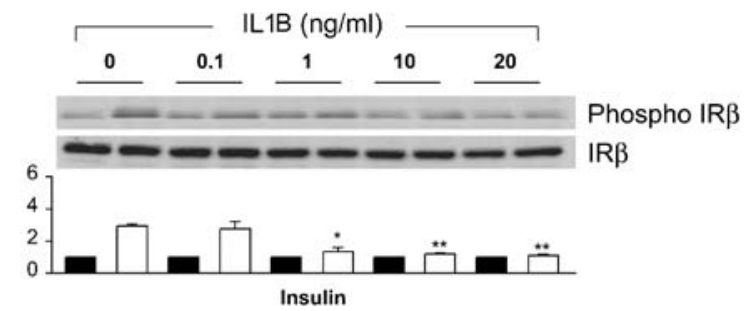

b

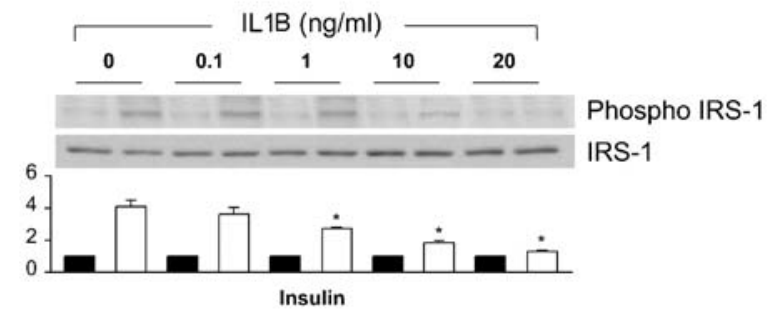

C

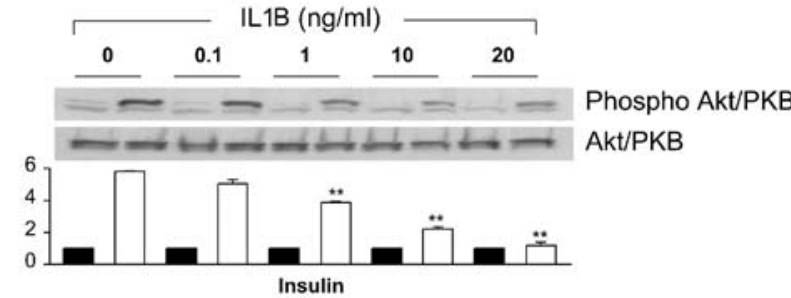

d

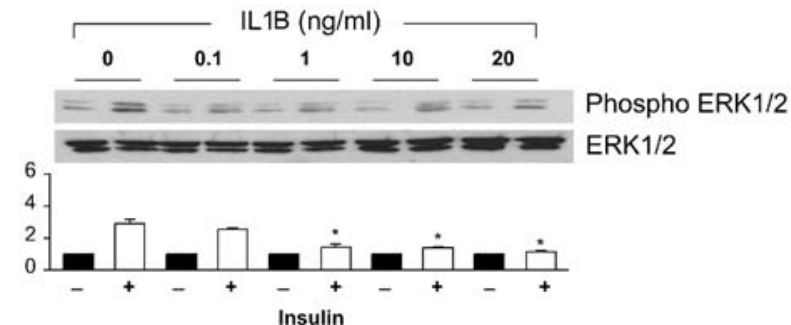

Fig. 5 IL1B alters insulin signalling in primary human adipocytes. Human adipocytes were treated with IL1B from days 22 to 28 at the concentration indicated. On day 28 , cells were cultured for $18 \mathrm{~h}$ in serum-free medium and stimulated for $10 \mathrm{~min}$ with $100 \mathrm{nmol} / \mathrm{l}$ insulin. Proteins were extracted and analysed by immunoblotting. Representative blots are shown of (a) the insulin receptor $\beta$ subunit $(\operatorname{IR} \beta)$ and its insulin-stimulated tyrosine phosphorylation, (b) IRS-1 and its insulin-stimulated tyrosine phosphorylation, (c) Akt/PKB and its phosphorylated form, and (d) ERK1/2 and its phosphorylated form. Scanned data expressed in arbitrary units are shown below and represent insulin-stimulated samples compared with their respective control sample (1.0) normalised to their protein expression. Results are mean \pm SEM for two or three experiments. ${ }^{*} p<0.05, * * p<0.01$

(Table 3). Expression of the gene for IL1B in epididymal adipose tissue was increased 3.3-fold $(p=0.006)$ in WT-HF vs WT-LF mice and 3.5-fold ( $p=0.01)$ in $o b / o b$ vs wild-type mice (Fig. 8a). Illb mRNA content correlated with the HOMA-IR index in WT-HF and WT-LF mice $(r=0.727$, $p=0.022$ ). Moreover, adiponectin mRNA expression was decreased in both WT-HF vs WT-LF mice (by 65\%) and $o b / o b$ vs wild-type mice (by $80 \%$ ) (Fig. 8b). Adipose tissue expression of the lipogenic enzyme FASN was also decreased by 60 to $90 \%$ in both mouse models of insulin resistance, and LPL was decreased in $o b / o b$ mice compared with WT littermates (Fig. 8c,d). Taken together, these results indicate that IL1B could contribute to the development of insulin resistance.

\section{Discussion}

Inflammation and macrophage infiltration of adipose tissue is suspected to play a key role in the pathogenesis of insulin resistance [3, 4]. Upon activation, macrophages secrete several proinflammatory cytokines, such as TNF- $\alpha$, IL1B and IL6 [23, 24]. Adipose tissue inflammation is characterised by high secretion levels of IL6 and TNF- $\alpha$ that contribute to adipocyte insulin resistance $[25,28,29,36$, 37]. However, the direct effect of IL1B in insulin resistance in adipose cells has never been studied. We therefore investigated the impact of long-term treatment $(24 \mathrm{~h}$ and $6-$ 8 days) with IL1B (from 0.1 to $20 \mathrm{ng} / \mathrm{ml}$ ) on the development of insulin resistance in human adipocytes and measured $I l l b$ mRNA expression in the adipose tissue of two insulin-resistant mouse models.

We found that IL1B induced insulin resistance in both differentiating and differentiated cultured adipocytes. Indeed, long-term treatment with IL1B during the differentiation programme (3T3-F442A cells for 8 days) or after completion of adipogenesis (3T3-L1 cells and human adipocytes for 6 days) induced cellular insulin resistance. IL1B acted at the early steps of insulin signalling by affecting the tyrosine phosphorylation of IR $\beta$ and its major substrate IRS-1 in all cell lines, in keeping with a recent study performed on a rat pancreatic cell line [38]. Moreover, insulin failed to activate Akt/PKB and ERK1/2, which is consistent with its negative effect on insulininduced glucose transport and lipogenesis.

In a more acute condition ( $24 \mathrm{~h}$ of treatment), IL1B induced insulin resistance in 3T3-L1 differentiated cells, as shown by the marked inhibition of the insulin-induced phosphorylation of Akt/PKB and ERK1/2. IL-1 $\alpha$, like IL1B, can rapidly decrease IRS-1 insulin-induced tyrosine phosphorylation in 3T3-L1 differentiated adipocytes [39], suggesting that both IL- $1 \alpha$ and IL- $1 \beta$, which act through the same receptor, can trigger insulin resistance in cultured adipocytes.

IL1B altered the lipid content of both murine and primary human adipose cell lines. In 3T3-F442A cells, IL1B impeded lipid accumulation during the differentiation process, whereas in 3T3-L1 mature adipocytes the effect of IL1B on the cellular lipid content was dependent on the length of the treatment. Indeed, a 6-day treatment affected the 3T3-L1 cell lipid content only slightly, but a further 4day treatment (10 days in total) induced a $60 \%$ fall in lipid content. This was probably due to IL1B increasing the basal rate of lipolysis and decreasing the level of mRNAs 
a

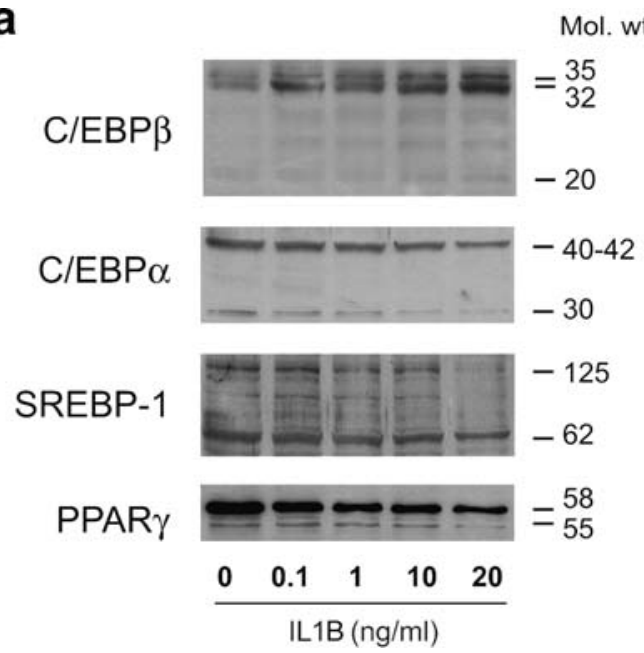

b

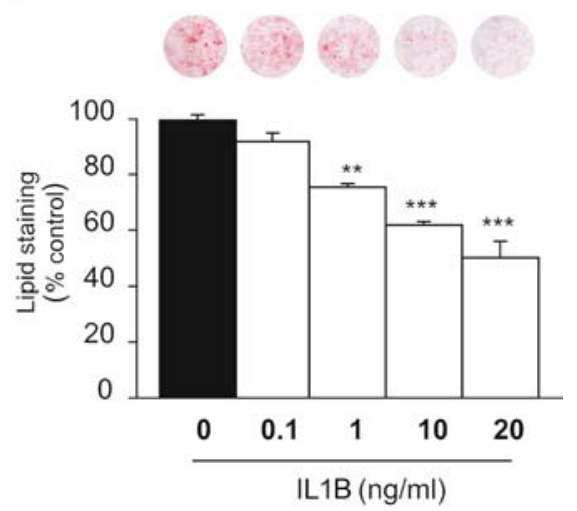

Fig. 6 IL1B decreases the level of adipogenic transcription factors and cellular lipid content in primary human adipocytes. Human adipocytes were treated with IL1B (see Fig. 5). a IL1B-treated and untreated adipocytes were solubilised and aliquots were immunoblotted with anti-C/EBP $\beta, \mathrm{C} / \mathrm{EBP} \alpha$, SREBP-1 and PPAR $\gamma$ antibodies. A represen-

encoding lipogenic enzymes (Fasn and Acac), and of other genes encoding proteins involved in lipid metabolism (Fabp4 and $L p l$ ). Human primary adipocytes treated with IL1B also exhibited decreased lipid accumulation and expression of genes involved in lipid metabolism.

In 3T3-F442A differentiating adipocytes, IL1B impeded the differentiation programme, as shown by the decreased levels of PPAR $\gamma$ and $\mathrm{C} / \mathrm{EBP} \alpha$ and the increased level of $\mathrm{C} /$ EBP $\beta$. In 3T3-L1 differentiated adipocytes, $\mathrm{C} / \mathrm{EBP} \alpha$ or $\operatorname{PPAR} \gamma$, two transcription factors that are involved in terminal differentiation, maintenance of the adipocyte phenotype, and insulin sensitivity $[33,40]$ were not affected by 6 days of treatment with IL1B, although the cells already displayed strong insulin resistance. The expression of adipogenic markers that increase with adipogenesis (Fasn, Acac, Lpl and Fabp4) was also affected after a 6day treatment of 3T3-L1 cells with IL1B, while differen-

tative immunoblot from three separate experiments is shown. b Cells were fixed and stained with Oil Red O. Staining was quantified at $520 \mathrm{~nm}$ and expressed as the percentage of untreated controls \pm SEM for three experiments performed in duplicate. ${ }^{* *} p<0.01, * * * p<0.001$ vs control (filled bars)

tiation was unaltered. Thus, under these conditions, IL1B appears to act on the establishment and maintenance of insulin responsiveness rather than on the adipocyte differentiation programme itself. In contrast, 10 days of treatment with IL1B significantly reduced $\mathrm{C} / \mathrm{EBP} \alpha$ and PPAR $\gamma$ and increased $\mathrm{C} / \mathrm{EBP} \beta$, indicating an alteration of the 3T3-L1 differentiation status. Similarly, in primary human adipocytes chronically treated (6 days) with IL1B at high concentrations (10 and $20 \mathrm{ng} / \mathrm{ml}), \mathrm{C} / \mathrm{EBP} \beta$ increased and $\operatorname{PPAR} \gamma, \mathrm{C} / \mathrm{EBP} \alpha$ and SREBP-1 decreased, which suggests dedifferentiation of these adipocytes.

The circulating adiponectin level is an index of insulin sensitivity $[14,15]$. Here we found that in both differentiating 3T3-F442A cells and fully differentiated 3T3-L1 adipocytes, and in human adipocytes, IL1B strongly attenuated adiponectin expression and secretion. Similarly it has been shown that TNF- $\alpha$ and IL6 strongly suppress

Table 2 Chronic effects of IL1B on the expression of adipogenic markers in primary human adipocytes

\begin{tabular}{|c|c|c|c|c|c|}
\hline & \multicolumn{5}{|c|}{ Primary human adipocytes } \\
\hline & \multicolumn{5}{|c|}{ IL1B (ng/ml) } \\
\hline & None & 0.1 & 1 & 10 & 20 \\
\hline$S L C 2 A 4$ & 100 & $103.1 \pm 6.0$ & $96.4 \pm 3.6$ & $77.8 \pm 2.9^{\mathrm{a}}$ & $56.7 \pm 4.9^{\mathrm{a}}$ \\
\hline FASN & 100 & $99.0 \pm 5.3$ & $55.3 \pm 6.6^{\mathrm{a}}$ & $36.4 \pm 2.1^{\mathrm{a}}$ & $34.9 \pm 2.0^{\mathrm{b}}$ \\
\hline$A C A C$ & 100 & $93.3 \pm 4.7$ & $81.6 \pm 10.2$ & $70.1 \pm 3.7^{\mathrm{a}}$ & $65.0 \pm 3.4^{\mathrm{b}}$ \\
\hline FABP4 & 100 & $102.2 \pm 5.3$ & $91.2 \pm 8.1$ & $46.7 \pm 1.6^{\mathrm{b}}$ & $43.9 \pm 5.2^{\mathrm{a}}$ \\
\hline$L P L$ & 100 & $52.1 \pm 4.4^{\mathrm{a}}$ & $28.4 \pm 2.0^{\mathrm{b}}$ & $20.2 \pm 6.9^{\mathrm{a}}$ & $10.9 \pm 2.3^{\mathrm{b}}$ \\
\hline
\end{tabular}

mRNA levels, normalised to $18 \mathrm{~S}$ rRNA expression, were determined relative to untreated cells (100). Results are expressed as percentage \pm SEM of control values in three experiments performed in duplicate

${ }^{\mathrm{a}} p<0.01,{ }^{\mathrm{b}} p<0.001$ vs untreated cells 
a

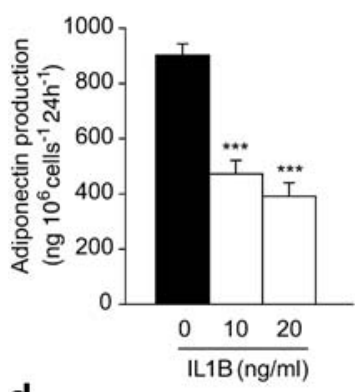

d

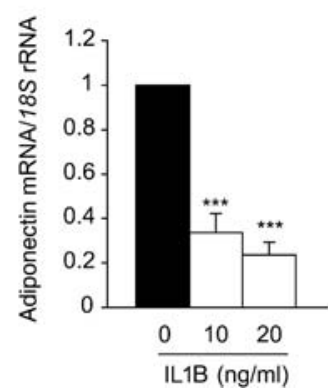

b

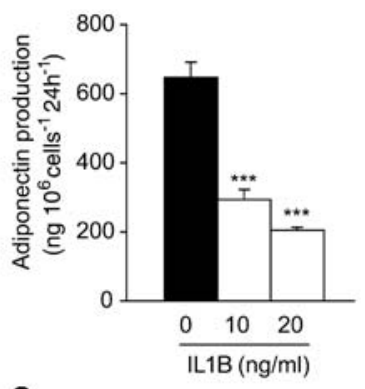

e

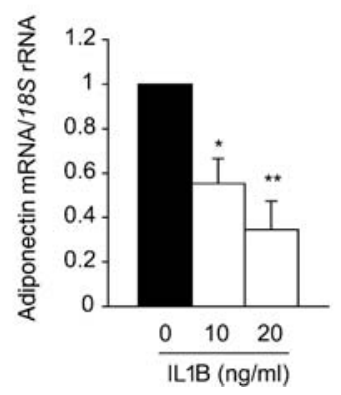

C

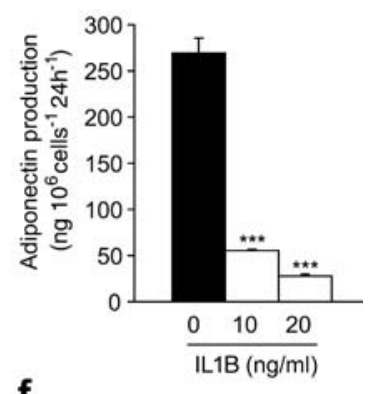

f

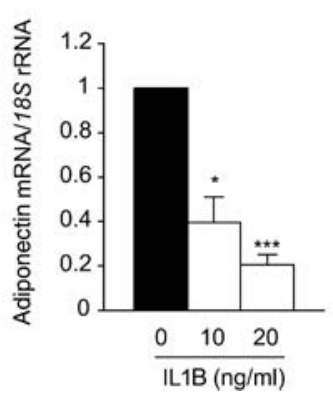

Fig. 7 IL1B decreases adiponectin secretion and expression in 3T3F442A, 3T3-L1 and human primary adipocytes. Differentiating 3T3F442A cells, fully differentiated 3T3-L1 adipocytes and differentiated human adipocytes were treated with IL1B. On day 8 (3T3-F442A) (a), 14 (3T3-L1) (b) or 28 (human adipocytes) (c) of differentiation, the medium was replaced and $24 \mathrm{~h}$ later the level of adiponectin in the cell medium was determined by ELISA. Results \pm SEM of three experiments performed in duplicate. Total RNA was extracted from (d) 3T3-F442A (e) 3T3-L1 and (f) human adipocytes and adiponectin mRNA levels normalised to $18 \mathrm{~S}$ rRNA expression were determined relative to untreated control cells. Results are percentage \pm SEM of control values in three or four experiments performed in duplicate. $* p<0.05, * * p<0.01, * * * p<0.001$ vs control (filled bars) adiponectin production [41], consistent with the antagonism between the action of adiponectin and proinflammatory cytokines [42]. Since IL1B can increase IL6 secretion in cultured adipocytes [17], part of the IL1B effect could be mediated by upregulation of IL6 release. Our finding that IL1B is also a potent inhibitor of adiponectin production in murine and human adipose cells is in line with data showing that IL1B suppresses the mRNA expression of adiponectin in human adipose tissue explants [13].

Finally, our results obtained with insulin-resistant mouse models add further evidence for the role of IL1B as an important mediator of insulin resistance in vivo. Indeed,
IL1B expression is increased three-fold in the epididymal adipose tissue of both genetic obese/insulin-resistant mice $(o b / o b)$ and mice with diet-induced insulin resistance (WTHF). These results are not in accordance with those found in a previous study that failed to find a significant increase of IL1B expression in epididymal adipose tissue of $o b / o b$ mice [21]. The increased expression of IL1B in the adipose tissue of insulin-resistant mice reported in the present study is in agreement with the decreased mRNA expression of adiponectin, Fasn and $\mathrm{Lpl}$. Moreover, IL1B expression in mouse adipose tissue was related to the degree of insulin resistance, as measured by the HOMA-IR index, supporting

Table 3 Metabolic parameters of insulin-resistant mouse models

\begin{tabular}{lllll}
\hline & $\begin{array}{l}\text { WT-LF } \\
(n=6)\end{array}$ & $\begin{array}{l}\text { WT-HF } \\
(n=6)\end{array}$ & $\begin{array}{l}\text { WT } \\
(n=7)\end{array}$ & $\begin{array}{l}o b / o b \\
(n=9)\end{array}$ \\
\hline Epididymal fat pad weight (g) & $0.28 \pm 0.02$ & $0.42 \pm 0.03^{\mathrm{a}}$ & $0.45 \pm 0.8$ & $2.83 \pm 0.19^{\mathrm{b}}$ \\
Fasting insulin (mU/l) & $42.9 \pm 2.2$ & $76.6 \pm 24.8^{\mathrm{a}}$ & $38.9 \pm 11.1$ & $510.3 \pm 169.9^{\mathrm{b}}$ \\
Fasting glucose (mmol/1) & $11.1 \pm 0.7$ & $11.29 \pm 0.3$ & $11.0 \pm 0.8$ & $11.0 \pm 0.9$ \\
HOMA-IR & $21.2 \pm 1.8$ & $38.9 \pm 10.9^{\mathrm{a}}$ & $19.0 \pm 5.5$ & $231.0 \pm 67.5^{\mathrm{b}}$ \\
\hline
\end{tabular}

All metabolic parameters were measured as indicated in Materials and methods. Insulin resistance was quantified by using the HOMA-IR in WT mice fed with a low-fat (LF) or a high-fat (HF) diet, and in $o b / o b$ mice and their littermate controls ${ }^{\mathrm{a}} p<0.05,{ }^{\mathrm{b}} p<0.001$ 

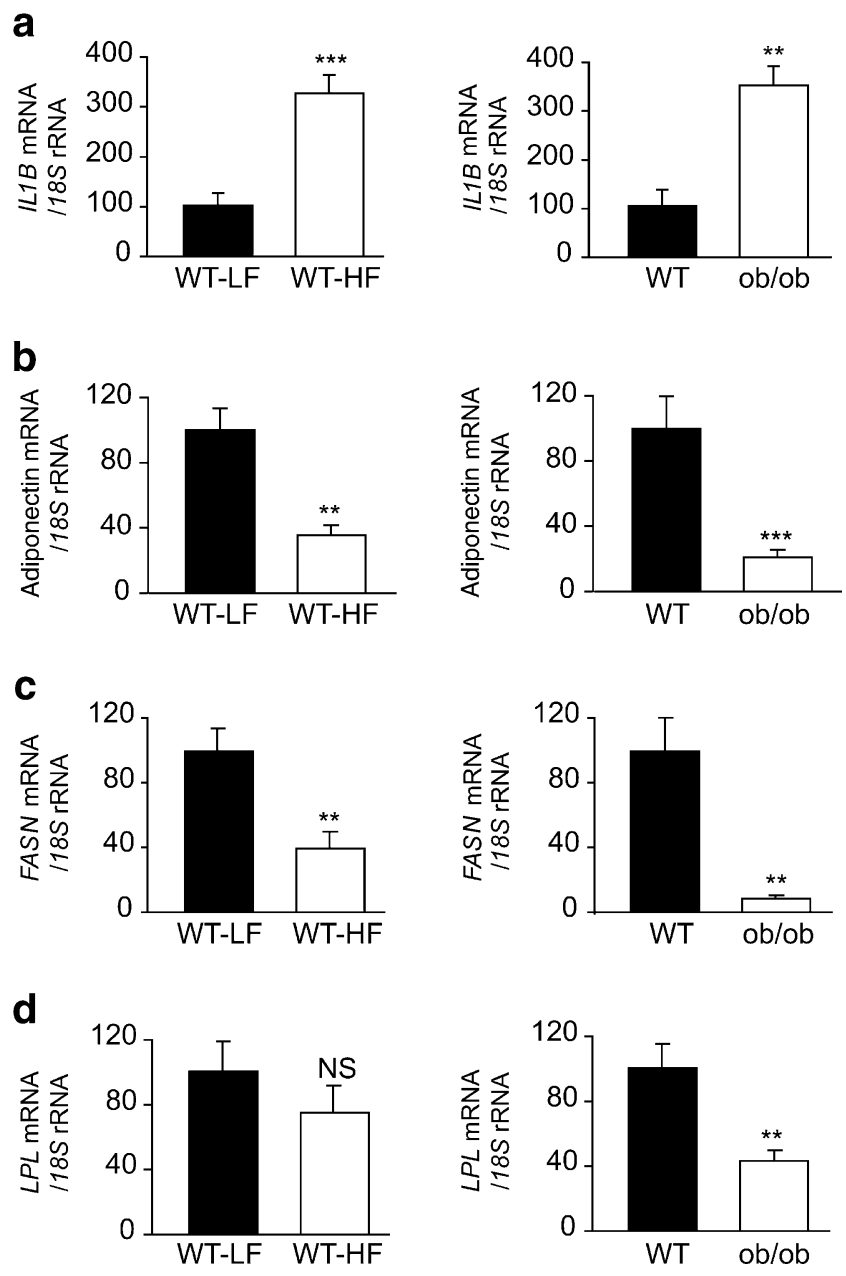

Fig. 8 Increased IL1B expression in epididymal adipose tissue from insulin-resistant mouse models. Total RNA was extracted and subjected to real-time PCR (see Materials and methods). a $I l l b$, b adiponectin, c Fasn and $\mathbf{d} L p l$ mRNA levels were normalised to $18 \mathrm{~S}$ rRNA expression and arbitrarily set at 100 for WT-LF and wild-type (filled bars) compared with WT-HF and ob/ob (open bars), respectively. Error bars represent SEM. ${ }^{* *} p<0.01,{ }^{* * *} p<0.001$ vs control (filled bars)

a role for IL1B in the development of insulin resistance [10]. These results are in keeping with previous results showing a 2.1- and 3.8-fold increase in IL1B-converting enzyme expression in WT-HF and $o b / o b$ mice, respectively [4]. IL1B-converting enzyme is necessary for the processing and subsequent secretion of bioactive IL1B [24]. However, the contribution of adipocytes to IL1B secretion by adipose tissue remains to be determined.

In conclusion, this study clearly indicates that IL1B induces insulin resistance in cultured murine and human adipocytes. Chronic exposure to IL1B inhibited insulin signal transduction in both differentiating and differentiated adipocytes. IL1B also altered the differentiation status of adipocytes. While we found that IL1B targeted IR $\beta$ and IRS-1 phosphorylation, the precise mechanism whereby IL1B triggers insulin resistance is unclear. IL1B, which is upregulated in adipose tissue of insulin-resistant mice, might be a key mediator of the adipose tissue inflammation that is associated with obesity and insulin resistance.

Acknowledgements We thank A. Goreau and J.-C. Martin for their contribution to some of the experiments. This work was supported by grants from INSERM. C. Lagathu and L. Yvan-Charvet are recipients of fellowships from the French Research Ministry.

\section{References}

1. Haffner SM, D’Agostino Jr R, Mykkanen L et al (1999) Insulin sensitivity in subjects with type 2 diabetes. Relationship to cardiovascular risk factors: the Insulin Resistance Atherosclerosis Study. Diabetes Care 22:562-568

2. Hotamisligil GS (2003) Inflammatory pathways and insulin action. Int J Obes 27(Suppl 3):S53-S55

3. Weisberg SP, McCann D, Desai M et al (2003) Obesity is associated with macrophage accumulation in adipose tissue. J Clin Invest 112:1796-1808

4. Xu H, Barnes GT, Yang Q et al (2003) Chronic inflammation in fat plays a crucial role in the development of obesity-related insulin resistance. J Clin Invest 112:1821-1830

5. Bastard JP, Maachi M, Tran Van Nhieu J et al. (2002) Adipose tissue IL-6 content correlates with resistance to insulin activation of glucose uptake both in vivo and in vitro. J Clin Endocrinol Metab 87:2084-2089

6. Bruun JM, Verdich C, Toubro S, Astrup A, Richelsen B (2003) Association between measures of insulin sensitivity and circulating levels of interleukin-8, interleukin-6 and tumor necrosis factor-alpha. Effect of weight loss in obese men. Eur J Endocrinol 148:535-542

7. Hotamisligil GS, Arner P, Caro JF, Atkinson RL, Spiegelman BM (1995) Increased adipose tissue expression of tumor necrosis factor-alpha in human obesity and insulin resistance. J Clin Invest 95:2409-2415

8. Bunout D, Munoz C, Lopez M et al (1996) Interleukin 1 and tumor necrosis factor in obese alcoholics compared with normalweight patients. Am J Clin Nutr 63:373-376

9. Um JY, Chung HS, Song MY, Shin HD, Kim HM (2004) Association of interleukin-1beta gene polymorphism with body mass index in women. Clin Chem 50:647-650

10. Spranger J, Kroke A, Mohlig M et al (2003) Inflammatory cytokines and the risk to develop type 2 diabetes: results of the prospective population-based European Prospective Investigation into Cancer and Nutrition (EPIC)-Potsdam Study. Diabetes $52: 812-817$

11. Fain JN, Madan AK, Hiler ML, Cheema P, Bahouth SW (2004) Comparison of the release of adipokines by adipose tissue, adipose tissue matrix, and adipocytes from visceral and subcutaneous abdominal adipose tissues of obese humans. Endocrinology $145: 2273-2282$

12. Juge-Aubry CE, Somm E, Chicheportiche R et al (2004) Regulatory effects of interleukin (IL)-1, interferon-beta, and IL-4 on the production of IL-1 receptor antagonist by human adipose tissue. J Clin Endocrinol Metab 89:2652-2658

13. Lihn AS, Bruun JM, He G et al (2004) Lower expression of adiponectin mRNA in visceral adipose tissue in lean and obese subjects. Mol Cell Endocrinol 219:9-15

14. Berg AH, Combs TP, Scherer PE (2002) ACRP30/adiponectin: an adipokine regulating glucose and lipid metabolism. Trends Endocrinol Metab 13:84-89 
15. Weyer C, Funahashi T, Tanaka S et al (2001) Hypoadiponectinemia in obesity and type 2 diabetes: close association with insulin resistance and hyperinsulinemia. J Clin Endocrinol Metab 86:1930-1935

16. Fain JN, Bahouth SW, Madan AK (2005) Involvement of multiple signaling pathways in the post-bariatric induction of IL-6 and IL8 mRNA and release in human visceral adipose tissue. Biochem Pharmacol 69:1315-1324

17. Flower L, Gray R, Pinkney J, Mohamed-Ali V (2003) Stimulation of IL-6 release by IL-1beta from isolated human adipocytes. Cytokine 21:32-37

18. Bruun JM, Lihn AS, Pedersen SB, Richelsen B (2005) Monocyte chemoattractant protein-1 release is higher in visceral than subcutaneous human adipose tissue (AT): implication of macrophages resident in the AT. J Clin Endocrinol Metab 90:2282-2289

19. Fain JN, Madan AK (2005) Regulation of monocyte chemoattractant protein 1 (MCP-1) release by explants of human visceral adipose tissue. Int $\mathrm{J}$ Obes 29:1299-1307

20. Christiansen T, Richelsen B, Bruun JM (2005) Monocyte chemoattractant protein-1 is produced in isolated adipocytes, associated with adiposity and reduced after weight loss in morbid obese subjects. Int J Obes 29:146-150

21. Juge-Aubry CE, Somm E, Giusti V et al (2003) Adipose tissue is a major source of interleukin-1 receptor antagonist: upregulation in obesity and inflammation. Diabetes 52:1104-1110

22. Somm E, Cettour-Rose P, Asensio C et al (2006) Interleukin-1 receptor antagonist is upregulated during diet-induced obesity and regulates insulin sensitivity in rodents. Diabetologia 49:387-393

23. Fantuzzi G (2005) Adipose tissue, adipokines, and inflammation. J Allergy Clin Immunol 115:911-919; quiz 920

24. Wewers MD (2004) IL-1beta: an endosomal exit. Proc Natl Acad Sci USA 101:10241-10242

25. Lagathu C, Bastard JP, Auclair M et al (2003) Chronic interleukin-6 (IL-6) treatment increased IL-6 secretion and induced insulin resistance in adipocyte: prevention by rosiglitazone. Biochem Biophys Res Commun 311:372-379

26. Lagathu C, Bastard JP, Auclair M et al (2004) Antiretroviral drugs with adverse effects on adipocyte lipid metabolism and survival alter the expression and secretion of proinflammatory cytokines and adiponectin in vitro. Antivir Ther 9:911-920

27. Zhang HH, Kumar S, Barnett AH, Eggo MC (2001) Dexamethasone inhibits tumor necrosis factor-alpha-induced apoptosis and interleukin-1 beta release in human subcutaneous adipocytes and preadipocytes. J Clin Endocrinol Metab 86:2817-2825

28. Hotamisligil GS, Peraldi P, Budavari A et al (1996) IRS-1-mediated inhibition of insulin receptor tyrosine kinase activity in TNF-alphaand obesity-induced insulin resistance. Science 271:665-668
29. Rotter V, Nagaev I, Smith U (2003) Interleukin-6 (IL-6) induces insulin resistance in 3T3-L1 adipocytes and is, like IL-8 and tumor necrosis factor-alpha, overexpressed in human fat cells from insulin-resistant subjects. J Biol Chem 278:45777-45784

30. Sethi J, Hotamisligil G (1999) The role of TNF alpha in adipocyte metabolism. Semin Cell Dev Biol 10:19-29

31. Briquet-Laugier V, Dugail I, Ardouin B et al (1994) Evidence for a sustained genetic effect on fat storage capacity in cultured adipose cells from Zucker rats. Am J Physiol 267:E439-E446

32. Chirgwin JM, Przybyla AE, MacDonald RJ, Rutter WJ (1979) Isolation of biologically active ribonucleic acid from sources enriched in ribonuclease. Biochemistry 18:5294-5299

33. Wu Z, Rosen ED, Brun R et al (1999) Cross-regulation of C/EBP alpha and PPAR gamma controls the transcriptional pathway of adipogenesis and insulin sensitivity. Mol Cell 3:151-158

34. Mauvais-Jarvis F, Kulkarni RN, Kahn CR (2002) Knockout models are useful tools to dissect the pathophysiology and genetics of insulin resistance. Clin Endocrinol (Oxf) 57:1-9

35. Radziuk J (2000) Insulin sensitivity and its measurement: structural commonalities among the methods. J Clin Endocrinol Metab 85:4426-4433

36. Dandona P, Aljada A, Bandyopadhyay A (2004) Inflammation: the link between insulin resistance, obesity and diabetes. Trends Immunol 25:4-7

37. Feingold KR, Doerrler W, Dinarello CA, Fiers W, Grunfeld C (1992) Stimulation of lipolysis in cultured fat cells by tumor necrosis factor, interleukin-1, and the interferons is blocked by inhibition of prostaglandin synthesis. Endocrinology 130:10-16

38. Emanuelli B, Glondu M, Filloux C, Peraldi P, Van Obberghen E (2004) The potential role of SOCS-3 in the interleukin-1betainduced desensitization of insulin signaling in pancreatic betacells. Diabetes 53 (Suppl 3):S97-S103

39. He J, Usui I, Ishizuka K et al (2005) Interleukin-1alpha inhibits insulin signaling with phosphorylating IRS-1 on serine residues in 3T3-L1 adipocytes. Mol Endocrinol 20:114-124

40. Cowherd RM, Lyle RE, McGehee RE Jr (1999) Molecular regulation of adipocyte differentiation. Semin Cell Dev Biol 10:3-10

41. Bruun JM, Lihn AS, Verdich C et al (2003) Regulation of adiponectin by adipose tissue-derived cytokines: in vivo and in vitro investigations in humans. Am J Physiol Endocrinol Metab 285:E527-E533

42. Maeda N, Takahashi M, Funahashi T et al (2001) PPARgamma ligands increase expression and plasma concentrations of adiponectin, an adipose-derived protein. Diabetes 50: 2094-2099 